officers possess great power of dotermining the fate of the inhabitants of the areas under their control, and whilo complaints have been made here and there of excessive shooting on tho part of the officers themselves, in most areas thoir infuence tells for the preservation of forest animals. Fluetuations in numbers must be expected, and in the United Provinces, while tigers appear to have incroased in numbers, marked decreases seem to have taken place amongst nilgai, kakar, wild dog and black buck. The decreases are attributod to serious floods and rinderpest epidemics, and these may be tem. porary; but the decrease of wild dogs is duo to the large reward paid for their destruction. It is unfor. tunate that the author speaks with two voices about the relative abundance of game at the present day.

\section{Gradual Decrease of Game in Reserved Forests}

In the carlier part of his article, Mr. Champion gives as his defirite conclusion that "taken as a whole the head of gume shot recently has generally shown no marked decrease, except in the mountain reserved forests, where control is not so easy", and again "the impression of senior forest officers is that. . . the game in the United Provinees Reserved Forests as a whole has not markedly decreased during the last 25 years, except in the high hill forest.8". But before conduding his article he reconsidors the matter, and the result is by no means so encouraging: "I tm not so certain as I was that the head of game insicle the United Provinces Reserved Forests is not decreasing. . . Although still a good place for animals in 1931. I would estimate that there had been at lcast a 25 per cent decrease in neariy all species during the previous decade." The decrease he puts down to the nase with which shooting can now be prosecuted owing to motor cars, and the destruction of game in areas outsicfe the forests, which results in a smaller influx into the forests, and along with this the greater damage done to animals straying from the forests. Although the position in the reserved forests is not so serious as in outlying areas, it appears to have definitely deteriorated, and in view of this it is unfortunate that the earlior misleading statement was not deleted or modified before the article appeared in print.

\section{Electrical Control of Road Traffic by Vehicle Actuation}

The control of road traflic by means of vehicle. actuated signals is making rapid progress. In a paper read to the Institution of Fletrical lingineers on January 24 by Mr. 'T. P'. Preist, the relative merits of the control of road traffic by traffic officers and by time-controlled signals are discussed. The great advantage of 1 sing traftic offeces is that they are able to talke advantage of any useful break in a heavy stream of traffic and so reduce the time interfereneo to a minimum. A drawback is that they are not conspicuous; this could be reduced by mounting them on a raised platform or orow's nest, but even this is not always effectivo, sund a driver in the rear has to deduce the signals from the movements of the vehicles ahead. They also favour unduly horse. drawn vehicles and stragglers. With automatic lamps the signals are highly visible and control the traffic of vehicles before officers could sce thom from the eross-roads. On tho other hand, the system is quite inflexible and may lead to much waste of time. Although railway practice has provided much valuable information to designers of road traffic control, there is a great difference between the fixed path of the railway train and the haphazard patlis of the road vehicle. Mr. Preist pointed out a useful analogy botween tho road traffic problom and the problems that ariso in tolephony. Both arts have to select and control priticular paths from the total available and ensure the orderly passage of the chance traftic arriving on those paths. In telephony the 'traffic' is concerned more with areas than with interscetions, and future progress of road traffic control will probably lie in this direction.

\section{Recent Acquisitions at the Natural History Mureum}

Amosg the recent acquisitions at the British Museum (Natural History) is a collection of 910 Coleoptera comprising 197 unmed species of Carabida (Trechina) and 257 spcoies of Silphidxe (Bathyseinæe and Catopinæ) received from $D r . ~ R$. Jeanrel, director of the Museum d'Histoire Nuturelle of Paris. The main interest of these two groups of boetles is that they include the beetles that inhabit the cxtensive limestone caverns both of Europe and America. In the course of the ages that have clapsed since their ancestors left the free air and sunlight, various modifications for a caverricolous habit have been evolved; thus, they have completely lost their cyes, their colour is an almost uniform redish yellow, their legs have tended to lengthen while their wings have tendexl to disappear, and in some groups have been entirely lost, and their long isolation as separate colonies has brought about the evolution of distinet species in each different system of cavorns, The Department of Mineralogy has received by exchange a portion (4,036 gm.) of a new meteoric stone from Lake Labyrinth in South Australia. A large ser'ies of specimens from the Ijibyan Desert has beer collected by Dr. L. J. Spencer, keeper of minerals, whilo on the expedition of the Survoy of Egypt to the Sand Sea in December. The object of the expedition was to investigate the origin of the lumps of pure silica-glass found on the surface in the stony or gravel 'strects' fretween the high (300 ft.) northsouth dimes near the borker of Italian Cyrenuica. Wind-worn pieces of clear glass were found in abundance vver an area of $200 \mathrm{~km}$. $\times 40 \mathrm{~km}$., the largest lump weighing $16 \mathrm{lb}$. Many of the piecest had been broken by primitive man and were associated with hundreds of thousands of flakes of glasss and quartzitc. Querns and grinding stones were frequently found, and at one spot sixty fine paliodithic axas of quartzite, 8-10 in. long, were found. The region must at one time have supported a large population, but now not a living animul or plant is to be sem. Unfortunately, the glass could not be traced to any source. Another kind of silica-glass was found in the form of lightning-tubes or fulgurites, made by 